\title{
Pengaruh Komisaris Independen, Dewan Pengawas Syariah, Kepemilikan Institusional, dan Profitabilitas Terhadap Tingkat Pengungkapan Tanggung-jawab Sosial pada Bank Syariah di Indonesia
}

\section{RENA MUSTARI MOKOGINTA ${ }^{1}$, HERMAN KARAMOY ${ }^{2}$, LINDA LAMBEY ${ }^{3}$}

\author{
${ }^{1,2,3}$ Program Magister Akuntansi, Fakultas Ekonomi dan Bisnis Universitas Sam Ratulangi \\ email: mokogintana@yahoo.com ${ }^{1}$, hkaramoy@yahoo.com², lindalambey@yahoo.com ${ }^{3}$
}

\begin{abstract}
This purpose of this study is aimed to analyze the influence of independent commissioners on the level of disclosure of social responsibility, the influence of the Shariah Supervisory Boards (SSB) on the level of social responsibility disclosure, the influence of institusional ownership on the level of social responsibility disclosure and profitability influence on the level of social responsibility disclosure on shariah bank in Indonesia. The number of observations in this study is 68 years of sharia bank of 13 sharia commercial banks registered in Sharia Banking Statistics of the Financial Services Authority period 2008-2016. This study uses secondary data which are in the form of annual reports obtained through the official website of each sharia commercial bank. Hypothesis testing is conducted by using multiple linier regression analysis method with SPSS version 21. The result showed that hypothesis 1 that is independent commissioner does not have an effect on social responsibility disclosure level, hypothesis 2 that is sharia supervisory board influences to disclosure level of responsibility, hypothesis 3 that is institutional ownership does not affect the level of social responsibility disclosure and hypothesis 4 that is profitability does not affect the level of social responsibility disclosure.
\end{abstract}

Keywords: disclosure, social responsibility, independent commissioner, sharia supervisory board, institutional ownership, and profitability

\begin{abstract}
Abstrak. Tujuan dalam penelitian ini adalah untuk menganalisis pengaruh komisaris independen terhadap tingkat pengungkapan tanggung jawab sosial, pengaruh Dewan Pengawas Syariah (DPS) terhadap tingkat pengungkapan tanggung jawab sosial, pengaruh kepemilikan institusional terhadap tingkat pengungkapan tanggung jawab sosial dan pengaruh profitabilitas terhadap tingkat pengungkapan tanggung jawab sosial pada bank syariah di Indonesia. Jumlah observasi dalam penelitian ini adalah 68 tahun bank syariah dari 13 bank umum syariah yang terdaftar di Statistik Perbankan Syariah Otoritas Jasa Keuangan periode 2008-2016. Penelitian ini menggunakan data sekunder yaitu berupa laporan tahunan yang diperoleh melalui website resmi tiap-tiap bank umum syariah. Pengujian hipotesis dilakukan dengan menggunakan metode analisis regresi linier berganda dengan bantuan SPSS versi 21. Hasil penelitian menunjukkan bahwa hipotesis 1 yaitu komisaris independen tidak berpengaruh terhadap tingkat pengungkapan tanggung jawab sosial, hipotesis 2 yaitu dewan pengawas syariah berpengaruh terhadap tingkat pengungkapan tanggung jawab, hipotesis 3 yaitu kepemilikan institusional tidak berpengaruh terhadap tingkat pengungkapan tanggung jawab sosial dan hipotesis 4 yaitu profitabilitas tidak berpengaruh terhadap tingkat pengungkapan tanggung jawab sosial.
\end{abstract}

Kata Kunci: Pengungkapan, tanggung jawab sosial, komisaris independen, dewan pengawas syariah (DPS), kepemilikan institusional, dan profitabilitas

\section{PENDAHULUAN}

Paradigma mengenai lingkungan bisnis saat ini sudah mengalami pergeseran dan perubahan dimana tujuan utama perusahaan bukan hanya terfokus pada pertumbuhan ekonomi atau perolehan profit (laba), akan tetapi dapat memberikan kontribusi positif dengan jalan mensinergikan berbagai kekuatan di dalam lingkar perusahaan dengan kekuatan di luar lingkar perusahaan. Untuk mewujudkan sinergisitas tersebut salah satunya adalah melalui pengungkapan tanggung jawab sosial (corporate social responsibility disclosure) yang meningkat. Tujuan utama tersebut sejalan dengan tujuan dasar penyajian dalam penyusunan laporan keuangan perbankan syariah yang harus menampilkan dua nilai secara seimbang yaitu nilai materi (laba) dan nilai non materi (nilai sosial dan lingkungan).

Ghutrie dan Mathews (1985) mendefinisikan corporate social disclosure (CSD) sebagai penyediaan informasi keuangan dan non-keuangan yang berkaitan dengan interaksi organisasi dengan lingkungan fisik dan sosialnya, sebagaimana tercantum dalam laporan tahunan perusahaan atau laporan sosial yang terpisah (Hackston dan Milne, 1996 dan Aribi dan Gao, 2010). Pengungkapan tanggung jawab sosial sendiri diatur dalam peraturan Otoritas Jasa Keuangan nomor 29 tahun 2016 
tentang laporan tahunan emiten atau perusahaan publik bab II mengenai penyusunan, bentuk, dan isi laporan tahunan dalam pasal 4 menyatakan laporan tahunan wajib paling sedikit memuat informasi mengenai salah satunya poin $\mathrm{h}$ yaitu tanggung jawab sosial dan lingkungan emiten atau perusahaan publik.

Konsep pengungkapan tanggung jawab sosial dalam perspektif Islami adalah akuntabilitas. Akuntabilitas dalam Islami ada 2 tipe yaitu akuntabilitas kepada Allah SWT dan akuntabilitas kepada masyarakat (Rahman dan Bukair, 2013). Melakukan tingkat pengungkapan tanggung jawab sosial adalah bentuk utama pertanggungjawaban bank syariah kepada Allah SWT sebagai sumber hukum utama dan kemudian kedua kepada pihak stakeholders.

Dilihat dari sisi shariah enterprise theory, tingkat pengungkapan tanggung jawab sosial berdasarkan prinsip syariah sangat penting karena dapat menambah keyakinan dan nilai positif khususnya bagi umat (kelompok masyarakat muslim) bahwa bank syariah bukan hanya mementingkan kepentingan stakeholders tetapi mengutamakan ketaqwaan kepada Allah SWT. Tugas melakukan tingkat pengungkapan tanggung jawab sosial memiliki dasar landasan hukum syariah yaitu berdasarkan Al-Qur'an (firman Tuhan) dan sunah (perbuatan dan ucapan Nabi Muhammad). Berdasarkan firman Allah SWT yang artinya "dan janganlah kamu campur adukkan yang hak dengan yang bathil dan janganlah kamu sembunyikan yang hak itu, sedang kamu mengetahui" (Al-Qur'an, 2:42).

Beberapa bank syariah sedikit berupaya untuk mengungkapkan corporate social responsibility mereka secara konsisten dan memastikan kesesuaian antara fakta yang terjadi dalam laporan dan tolak ukur pengungkapan corporate social responsibility (Hassan dan Harahap, 2010). Selain itu, pengungkapan tanggung jawab sosial sendiri yang diungkapkan merupakan informasi yang bersifat sukarela sehingga membuat bank syariah bebas mengungkapkan informasi tanggung jawab sosial. Hal tersebut berdampak pada perbedaan tingkat pengungkapan tanggung jawab sosial masing-masing bank syariah.

Bank syariah pada umumnya tidak mengungkapkan informasi tentang kegiatan yang dapat menarik kritik, seperti transaksi tidak halal dan kebijakan mereka dalam menangani nasabah yang bangkrut (Maali et al, 2006). Beberapa bank syariah membebankan biaya atau bunga jika ada keterlambatan pembayaran oleh nasabah yang bangkrut atau gagal memenuhi kewajibannya yang jatuh tempo. Bunga ini termasuk dalam riba sehingga tidak halal berdasar prinsip syariah. Hasil penelitian Maali et al (2006) tidak ada satu pun bank termasuk dalam sampel penelitian yang mengungkapkan bagaimana pihak bank dalam menanggulangi nasabah pailit tersebut. Ini menunjukkan bahwa bank syariah mungkin menghindari isu-isu yang dapat mempengaruhi citra Islami mereka, sementara di sisi lain mereka memberikan lebih banyak pengungkapan mengenai kegiatan amal dan keterlibatan mereka di masyarakat (Maali et al, 2006).

Hasil penelitian yang dilakukan oleh Gustani (2013) pada Bank Umum Syariah (BUS) di Indonesia periode 2009-2011 menunjukkan bahwa secara keseluruhan tingkat pengungkapan kinerja sosial di Indonesia masih kurang normatif. Dari kelima bank umum syariah yang diteliti yaitu Bank Muamalat Indonesia (BMI), Bank Syariah Mandiri (BSM), Bank Mega Syariah (BMS), Bank Rakyat Syariah Indonesia (BRSI), dan Bank Syariah Bukopin (BSB) diperoleh uji rata-rata 65.6\%, 76\%, $58.7 \%, 46.8 \%$, dan $48.7 \%$. Dapat dilihat, yang memiliki tingkat pengungkapan kinerja sosial tertinggi adalah BSM dengan nilai rata-rata sebesar 76\% sedangkan terendah adalah BRIS dengan nilai 46,8\%.

Beberapa faktor yang mempengaruhi tingkat pengungkapan tanggung jawab sosial diantaranya adalah komposisi independen, Dewan Pengawas Syariah (DPS), kepemilikan institusional dan profitabilitas. Berdasarkan Surat Edaran Otoritas Jasa Keuangan nomor 30 tahun 2016 tentang bentuk dan isi laporan tahunan emiten atau perusahaan publik dalam bagian I mengenai ketentuan umum nomor 2 menyatakan bahwa dewan komisaris dituntut untuk meningkatkan kualitas keterbukaan informasi melalui laporan tahunan perusahaan. Salah satu keterbukaan informasi tersebut adalah tanggung jawab sosial dan lingkungan. Dewan komisaris independen dipandang lebih baik karena akan menerapkan kebijakan yang berkaitan dengan perusahaan secara lebih obyektif dibanding perusahaan yang memiliki susunan dewan komisaris yang hanya berasal dari dalam perusahaan (Sulistyawati, 2016). Komisaris independen sendiri adalah sebuah badan dalam perusahaan yang biasanya beranggotakan dewan komisaris independen yang berasal dari luar perusahaan yang berfungsi untuk menilai kinerja perusahaan secara luas dan keseluruhan (Mariana, 2016). Semakin besar persentase anggota yang berasal dari luar perusahaan (komisaris independen) akan menjadikan peranan dewan komisaris semakin efektif dalam melaksanakan fungsi pengawasan terhadap pengelolaan perusahaan, karena dianggap semakin independen (Nuryaman, 2009). Dewan pengawas 
syariah sendiri merupakan dewan yang memiliki tugas memberikan nasihat dan saran kepada pihak direksi dan mengawasi kegiatan bank agar sesuai dengan prinsip syariah. Bank-bank syariah yang memiliki lebih banyak anggota Shariah Supervisory Boards (SSB) atau dewan pengawas syariah di bidang industri perbankan syariah memutuskan untuk memberikan lebih banyak informasi mengenai corporate social responsibility (Rahman dan Bukair, 2013). Kepemilikan institusional sendiri adalah jumlah saham yang dimiliki oleh investor institusional (bank, asuransi, dan lembaga pembiayaan non bank). Tingkat kepemilikan institusional yang tinggi akan menimbulkan usaha pengawasan yang lebih besar oleh pihak investor institusional sehingga dapat menghalangi perilaku opportunistic manajer (Nurkhin, 2009). Profitabilitas dapat diartikan sebagai alat ukur kesuksesan sebuah perusahaan yang dapat membuat manajemen bebas dan fleksibel dalam melakukan pengungkapan kepada masyarakat tanpa dipengaruhi oleh bagaimana perolehan aset atau modal. meskipun laba bank syariah yang diperoleh meningkat atau pun menurun, pengungkapan tanggung jawab sosial tetap dilakukan dalam laporan tahunan bahkan seharusnya mengalami peningkatan karena dana yang digunakan untuk melakukan pengungkapan tersebut bukan hanya berasal dari laba tetapi dapat berasal dari dana zakat, pendapatan non-halal, infak, sedekah dan wakaf.

Untuk mengetahui tingkat pengungkapan tanggung jawab sosial berdasarkan syariah dapat menggunakan indeks Islamic social reporting. Indeks Islamic social reporting berisi item-item pengungkapan tanggung jawab sosial yang ditetapkan oleh AAOIFI (Accounting and Auditing Organization for Islamic Financial Institutions) yang kemudian dikembangkan oleh para peneliti sebelumnya dalam beberapa sub tema karena item-item yang harus diungkapkan belum disebutkan semua. berikut:

Berdasarkan pemaparan alasan di atas, maka perumusan masalah penelitian ini adalah sebagai

1. Apakah komisaris independen berpengaruh terhadap tingkat pengungkapan tanggung jawab sosial pada bank syariah di Indonesia?

2. Apakah dewan pengawas syariah berpengaruh terhadap tingkat pengungkapan tanggung jawab sosial pada bank syariah di Indonesia?

3. Apakah kepemilikan institusional berpengaruh terhadap tingkat pengungkapan tanggung jawab sosial pada bank syariah di Indonesia?

4. Apakah profitabilitas berpengaruh terhadap tingkat pengungkapan tanggung jawab sosial pada bank syariah di Indonesia?

Tujuan yang akan dicapai dalam penelitian ini adalah untuk menguji secara empiris semua rumusan masalah. Penelitian ini dapat memberikan manfaat diantaranya bagi pihak bank syariah, hasil penelitian ini dapat menjadi bahan masukan dalam kegiatan operasional perusahaan berkaitan dengan peningkatan pengungkapan tanggung jawab sosial; bagi pemerintah dan Ikatan Akuntansi Indonesia (IAI), hasil penelitian ini dapat menjadi pertimbangan berkaitan dengan penetapan standar akuntansi; dan bagi akademisi, hasil penelitian ini dapat menjadi salah satu referensi bagi penulis selanjutnya dalam melakukan penelitian yang berkaitan dengan tingkat pengungkapan tanggung jawab sosial.

\section{Gambar 1. Kerangka Konseptual Penelitian}

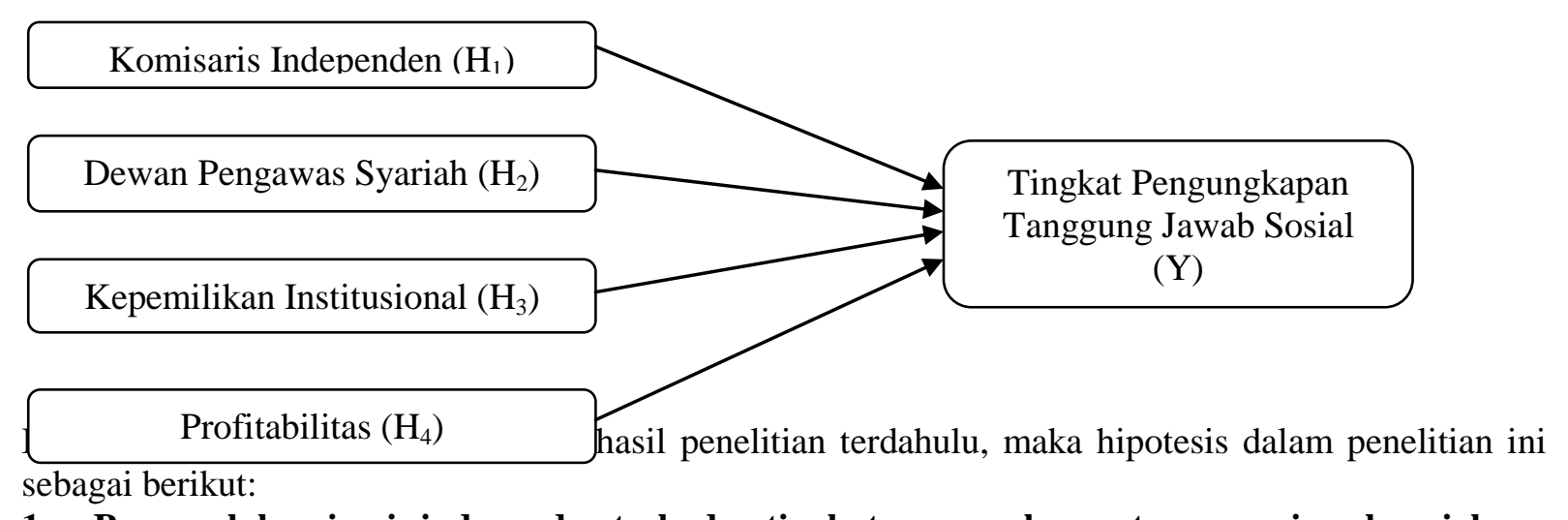

\section{Pengaruh komisaris independen terhadap tingkat pengungkapan tanggung jawab sosial}

Menurut Fahmi (2014:5) seorang komisaris independen adalah tidak memiliki saham namun ditunjuk untuk menjadi komisaris independen karena faktor kapasitas kepemilikan ilmu dan pengalaman dalam bidang tersebut telah diakui mampu memberi masukan kepada pihak dewan komisaris dalam setiap pengambilan keputusan, terutama keputusan-keputasan yang diusulkan oleh 
pihak manajemen perusahaan. Teori agensi menyatakan dewan komisaris yang berasal dari luar perusahaan (independen) akan dipandang lebih baik karena mereka akan menetapkan kebijakan yang berkaitan dengan perusahaan secara lebih obyektif dibanding perusahaan yang memiliki susunan dewan komisaris yang hanya berasal dari dalam perusahaan (Sulistyawati et al, 2016). Dalam teori agensi ini, komisaris independen sebagai pihak principal (stakeholders) artinya komisaris independen mewakili pihak stakeholders untuk mengawasi kinerja dari pihak agent (manajemen). Kehadiran komisaris independen sendiri tidak terafiliasi dengan perusahaan itu sendiri. Semakin besar persentase anggota yang berasal dari luar perusahaan (komisaris independen) akan menjadikan peranan dewan komisaris semakin efektif dalam melaksanakan fungsi pengawasan terhadap pengelolaan perusahaan, karena dianggap semakin independen (Nuryaman, 2009). Keberadaan komisaris independen dapat memberikan tekanan dan mendorong pihak manajemen untuk melakukan pengungkapan tanggung jawab sosial sehingga terpenuhinya peraturan yang sudah ditetapkan oleh Bank Indonesia atau pun Otoritas Jasa Keuangan sehingga diperolehnya status atau legalitas atau pun pengakuan dari masyarakat. Dengan demikian, tujuan perusahaan untuk mendapatkan legitimasi dari stakeholders dengan mengungkapkan tanggung jawab sosial akan dapat diperoleh karena keberadaan dewan komisaris independen akan memberikan pengendalian dan pengawasan (Nurkhin, 2009).

Hasil penelitian Nurkhin (2009) meneliti pada 80 perusahaan yang terdaftar di bursa efek Indonesia (BEI) tahun 2007 menunjukkan bahwa komisaris independen terbukti signifikan berpengaruh positif terhadap pengungkapan tanggung jawab sosial perusahaan. Hasil penelitian tersebut memberikan arti bahwa dewan komisaris independen yang dimiliki oleh perusahaan di Indonesia dapat menjalankan peran dan fungsinya. Sulistyawati dan Yuliani (2017) meneliti mengenai pengungkapan Islamic social reporting pada 39 perusahaan yang termasuk dalam indeks saham syariah Indonesia periode 2012 sampai 2014, hasil penelitian menunjukkan ukuran dewan komisaris independen berpengaruh signifikan dan positif terhadap Islamic social reporting. Pengaruh yang signifikan dan positif ini mengindikasikan bahwa semakin banyak ukuran dewan komisaris independen berdampak tajam pada pengungkapan Islamic social reporting. Dari uraian tersebut dapat dibuat hipotesis 1 sebagai berikut:

\section{$\mathrm{H}_{1}$ : komisaris independen berpengaruh positif dan signifikan terhadap tingkat pengungkapan tanggung jawab sosial}

\section{Pengaruh Dewan Pengawas Syariah (DPS) terhadap tingkat pengungkapan tanggung jawab sosial}

Dewan pengawas syariah (DPS) adalah suatu fungsi dalam organisasi bank syariah yang secara internal merupakan badan pengawas syariah, dan secara eksternal dapat menjaga serta meningkatkan kepercayaan masyarakat (Fahmi, 2014:40). Berdasarkan syariah enterprise theory atau Islamic enterprise theory beranggapan bahwa akuntansi atau laporan keuangan harus bisa memenuhi kebutuhan dalam menjelaskan kepada semua pihak bahwa entitas telah memenuhi atau sejauh mana memenuhi tanggung jawabnya kepada Tuhan dan kepada pihak yang diperintahkan Tuhan sesuai tujuan dan maksud yang ditetapkan syariat (Harahap, 2012:79). Salah satu pemenuhan tanggung jawab kepada Tuhan adalah dengan melakukan pengungkapan tanggung jawab sosial. Untuk itu diperlukan peran dari dewan pengawas syariah untuk mengawasi jalannya operasional perusahaan agar sesuai dengan prinsip syariah. Dengan adanya dewan pengawas syariah yang mengontrol dan mengawasi kinerja operasi perusahaan khususnya berkaitan dengan pengungkapan tanggung jawab sosial diharapkan perusahaan dapat membuat masyarakat, pemerintah, individu dan kelompok masyarakat untuk memberikan legalitas (pengakuan) kepada perusahaan dimana perusahaan sudah menjalankan kegiatan operasinya berdasar prinsip syariah dan juga berdasar peraturan yang sudah ditetapkan baik itu dari Bank Indonesia atau pun Otoritas Jasa Keuangan.

Hasil penelitian yang dilakukan oleh Inuzula (2017) pada 33 observasi dari 11 Bank Umum Syariah (BUS) di Indonesia dengan menggunakan indikator pengukuran adalah ukuran dewan pengawas syariah diperoleh hasil uji dewan pengawas syariah berpengaruh signifikan dalam pengungkapan Islamic social reporting. Dari uraian tersebut dapat dibuat hipotesis 2 sebagai berikut:

$\mathrm{H}_{2}$ : dewan pengawas syariah berpengaruh positif dan signifikan terhadap tingkat pengungkapan tanggung jawab sosial

\section{Pengaruh kepemilikan institusional terhadap tingkat pengungkapan tanggung jawab sosial}

Kepemilikan institusi merupakan persentase saham yang dimiliki oleh investor institusional yaitu investor dari sektor keuangan (bank, asuransi, perusahaan efek dan lembaga pembiayaan non 
bank) (Mariana, 2016). Tingkat kepemilikan institusional yang tinggi akan menimbulkan usaha pengawasan yang lebih besar oleh pihak investor institusional sehingga dapat menghalangi perilaku opportunistic manajer (Nurkhin, 2009). Semakin tinggi kepemilikan institusional maka semakin kuat kontrol eksternal terhadap perusahaan dan mengurangi kos keagenan (Dewi, 2008). Tujuan yang lebih luas dari teori stakeholder adalah untuk menolong manajer korporasi dalam meningkatkan nilai dari dampak aktifitas-aktifitas mereka, dan meminimalkan kerugian-kerugian bagi stakeholder (Yuniarti, 2007). Institusi memantau secara profesional perkembangan investasinya maka tingkat pengendalian terhadap tindakan manajemen sangat tinggi sehingga potensi kecurangan dapat ditekan (Murwaningsari, 2009). Potensi kecurangan dapat ditekan atau dikurangi artinya pihak manajemen lebih meningkatkan kesejahteraan bagi pihak stakeholders. Ini sejalan dengan visi dari perbankan syariah yang dapat memberikan manfaat bagi masyarakat. Teori agensi menjelaskan bagaimana hubungan kontraktual antara pihak pemilik perusahaan (principal) yang mendelegasikan pengambilan keputusan tertentu guna meningkatkan kesejahteraannya dengan pihak manajemen/pengelola (agent) yang menerima pendelegasian tersebut (Maksum, 2005). Adanya kepentingan ini dapat menimbulkan konflik kepentingan antara pihak principal dan stakeholders dengan pihak manajemen. Dengan demikian, kepemilikan institusional yang semakin tinggi sebagai pihak principal diharapkan dapat mengawasi kinerja pihak manajemen dalam hal peningkatan pengungkapan tanggung jawab sosial.

Farida et al (2010) meneliti mengenai pengaruh penerapan corporate governance terhadap timbulnya earning management dalam menilai kinerja keuangan pada perusahaan perbankan di Indonesia periode 2005 sampai 2007 dimana hasilnya kepemilikan institusional berpengaruh terhadap kinerja keuangan. Istighfarin dan Wirawati (2015) meneliti mengenai pengaruh good corporate governance terhadap profitabilitas pada 6 Badan Usaha Milik Negara (BUMN) dengan jumlah pengamatan sebanyak 30 data observasi selama periode 2009 sampai 2013 menghasilkan pengujian yang sama dimana kepemilikan institusional berpengaruh terhadap profitabilitas. Dari uraian tersebut dapat dibuat hipotesis 3 sebagai berikut:

\section{$\mathrm{H}_{3}$ : kepemilikan institusional berpengaruh positif dan signifikan terhadap tingkat pengungkapan tanggung jawab sosial}

\section{Pengaruh profitabilitas terhadap tingkat pengungkapan tanggung jawab sosial}

Profitabilitas merupakan alat ukur kesuksesan sebuah perusahaan yang utama (Libby et al, 2008:710). Dengan memperoleh laba yang maksimal seperti yang telah ditargetkan, perusahaan dapat berbuat banyak bagi kesejahteraan pemilik, karyawan, serta meningkatkan mutu produk dan melakukan investasi baru (Kasmir, 2011:196). Berdasarkan teori syariah enterprise theory, laporan keuangan harus bisa memenuhi kebutuhan dalam menjelaskan kepada semua pihak bahwa entitas telah memenuhi atau sejauh mana memenuhi tanggung jawabnya kepada Tuhan dan kepada pihak yang diperintahkan Tuhan sesuai tujuan dan maksud yang ditetapkan syariat (Harahap, 2012:79). Tanggung jawab sosial Islam adalah bagian dari penerapan prinsip syariah yang tidak hanya berorientasi pada keuntungan, tapi juga kehidupan akhirat (Lestari, 2013). Teori stakeholders menyatakan perusahaan bukanlah entitas yang hanya beroperasi untuk kepentingan sendiri namun harus mampu memberikan manfaat bagi stakeholdersnya (Sulistyawati dan Yuliani, 2017). Berdasarkan teori stakeholders, pihak manajemen harus bisa memberikan manfaat bagi pihak stakeholders ini sejalan dengan visi dari perbankan syariah yaitu memberikan kemaslahatan (manfaat) kepada masyarakat.

Hasil penelitian yang dilakukan oleh peneliti sebelumnya dengan menggunakan indikitor pengukuran return on assets diantaranya Othman et al (2009) melakukan penelitian pada 56 perusahaan syariah yang terdaftar di bursa Malaysia periode 2004 sampai 2006 hasilnya menyatakan bahwa ada hubungan signifikan profitability dengan Islamic social reporting. Penelitian Othman et al (2009) ini sejalan dengan Inuzula (2017) melakukan penelitian pada 33 observasi dari 11 bank umum syariah periode 2011-2013 dimana profitabilitas berpengaruh terhadap pengungkapan Islamic social reporting. Dari uraian tersebut dapat dibuat hipotesis 4 sebagai berikut:

\section{$\mathrm{H}_{4}$ : profitabilitas berpengaruh positif dan signifikan terhadap tingkat pengungkapan tanggung jawab sosial}

\section{Metode Penelitian}

Jenis penelitian ini termasuk dalam jenis penelitian kuantitatif. Data penelitian ini termasuk dalam data sekunder berupa dokumentasi dalam bentuk laporan tahunan (annual report) diperoleh dari alamat website masing-masing bank syariah. Berdasarkan waktu pengumpulan datanya, dalam penelitian ini menggunakan data cross section. Populasi dalam penelitian ini adalah jumlah laporan 
tahunan bank syariah yaitu bank umum syariah pada periode 2008-2016. Populasi dalam penelitian ini adalah jumlah laporan tahunan bank syariah yaitu Bank Umum Syariah (BUS) pada periode 20082016. Berdasarkan statistik perbankan syariah pada tahun 2008 sampai tahun 2016 jumlah bank umum syariah adalah sebanyak 13 buah sehingga jumlah laporan tahunan yang menjadi populasi adalah sebanyak 92 laporan tahunan.

\section{Definisi Operasional dan Pengukuran Variabel Variabel Dependen}

Variabel dependen dalam penelitian ini adalah tingkat pengungkapan tanggung jawab sosial yaitu jumlah skor perbandingan antara jumlah pengungkapan yang dilakukan perusahaan dengan jumlah pengungkapan yang seharusnya diungkapkan dalam laporan tahunan. Skala pengukuran tingkat pengungkapan tanggung jawab sosial dalam penelitian ini adalah rasio. Pengukuran tingkat pengungkapan tanggung jawab sosial dalam penelitian menggunakan rumus yang mengacu pada penelitian Haniffa dan Hudaib (2007), Nurkhin (2009), Lestari (2013), dan Inuzula (2017) sebagai berikut:

Keterangan:

$$
\text { Indeks skor } \mathrm{j}=\frac{\sum \mathrm{Xij}}{\mathrm{nj}}
$$

Indeks skor $\mathrm{j} \quad: \quad$ Indeks skor tingkat pengungkapan tanggung jawab sosial $\mathrm{j}$

Xij $\quad: \quad$ jumlah indeks dari item yang diungkapkan dengan memberi skor 0 jika tidak diungkapkan dan 1 jika diungkapkan,

nj : jumlah indeks dari item pengungkapan tanggung jawab sosial bank umum syariah.

Dengan demikian, $0<=$ indeks skor $\mathrm{j}<=1$

Indikator variabel dependen dalam penelitian ini menggunakan indeks Islamic social reporting yang mengacu pada penelitian Haniffa dan Hudaib (2007), Othman et al (2009), dan Rahman dan Bukair (2013) yang disesuaikan kembali oleh penulis.

\section{Variabel Independen}

\section{Komisaris Independen}

Komisaris independen yang dimaksud dalam penelitian ini adalah komposisinya yaitu jumlah komisaris independen yang berasal dari luar dewan komisaris atau luar pihak bank umum syariah dibandingkan dengan total jumlah dewan komisaris. Skala pengukuran komisaris independen adalah skala rasio dengan pengukuran menggunakan rumus yang mengacu pada pada penelitian Nurkhin (2009), dan Sulistyawati et al (2016) sebagai berikut:

$$
\text { Komisaris Independen }(\mathrm{KI})=\frac{\text { jumlah komisaris independen }}{\text { jumlah dewan komisaris }}
$$

\section{Dewan Pengawas Syariah}

Dewan pengawas syariah yang dimaksud dalam penelitian ini adalah jumlah anggota dari dewan pengawas syariah. Skala pengukuran dewan pengawas syariah adalah skala rasio dengan pengukuran menggunakan jumlah anggota dewan pengawas syariah yang mengacu pada penelitian Inuzula (2017) sebagai berikut:

Dewan pengawas syariah $=$ Jumlah anggota dewan pengawas syariah

\section{Kepemilikan Institusional}

Kepemilikan institusional yang dimaksud dalam penelitian ini adalah komposisi dari jumlah saham yang dimiliki oleh investor institusi (lembaga keuangan atau pun bukan lembaga pembiayaan bukan bank) dibandingkan dengan jumlah saham yang beredar di dalam Bank Umum Syariah (BUS). Skala pengukuran kepemilikan institusional adalah skala rasio dengan pengukuran menggunakan rumus yang mengacu pada penelitian Murwaningsari, (2009), Sugiarto (2011) sebagai berikut:

$$
\text { Kepemilikan Institusional (KepIns) }=\frac{\text { Jumlah saham dimiliki institusi }}{\text { Jumlah saham beredar di dalam BUS }}
$$




\section{Profitabilitas}

Profitabilitas dalam penelitian ini merupakan kemampuan Bank Umum Syariah (BUS) menciptakan laba bersih sebelum pajak dari total aset. Skala pengukuran profitabilitas adalah berdasarkan rasio dengan pengukuran menggunakan rumus yang mengacu pada penelitian Othman et al, (2009). Berikut rumus perolehan return on assets (Harmono, 2016:119) sebagai berikut:

$$
\text { ROA }=\frac{\text { Laba Sebelum Pajak }}{\text { Total Aktiva }}
$$

\section{Metode Analisis Data}

Untuk menganalisis data dalam penelitian ini menggunakan bantuan program software Statistical Package for Social Science (SPSS) 21. Metode analisis penelitian ini melalui beberapa tahapan yaitu pertama analisis statistik deskriptif terdiri dari uji nilai minimum, maksimum, mean, dan standar deviasi. Kedua uji asumsi klasik terdiri dari uji normalitas, uji multikolinearitas, uji autokorelasi, dan uji heteroskedastisitas. Ketiga pengujian hipotesis yaitu menggunakan teknik analisis regresi linear berganda dan melakukan interpretasi. Metode analisis keempat adalah menilai goodness of fit model terdiri dari 3 uji yaitu uji signifikan parameter individual (uji statistik t), uji signifikansi keseluruhan dari regresi sampel (uji statistik F), dan uji koefisien determinasi $\left(\mathrm{R}^{2}\right)$. Menilai goodness of fit model dilakukan untuk menjawab rumusan masalah penelitian ini.

\section{Hasil dan Pembahasan}

Dengan menggunakan kriteria-kriteria yang sudah ditentukan oleh penulis maka diperoleh jumlah observasi penelitian sebanyak 68 laporan tahunan dari 12 bank umum syariah.

\section{Uji Asumsi Klasik}

\section{Uji Normalitas}

Berikut gambar 5.1 mengenai grafik histogram:

\section{Gambar 5.1 Grafik Histogram}

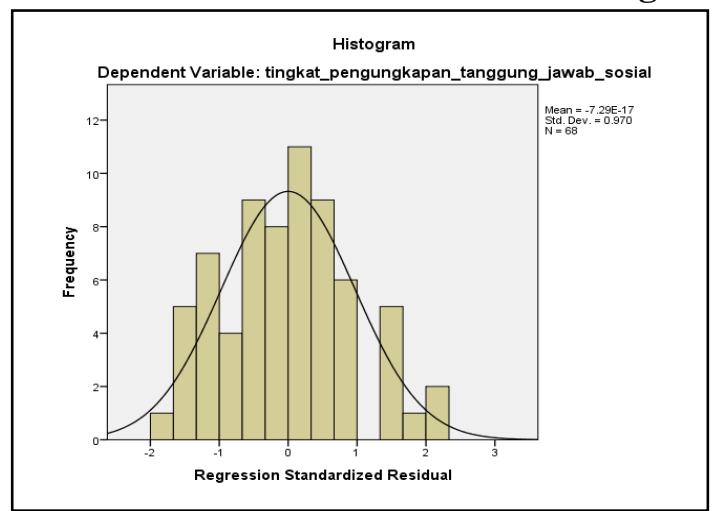

Sumber: Output SPSS, Hasil Olah Data 2018

Dari gambar 5.1 mengenai grafik di atas, dapat dilihat garis perbandingan antara data observasi dengan distribusi yang mendekati distribusi normal. Gambar grafik tersebut menunjukkan bahwa residual terdistribusi normal karena residual berbentuk simetri dimana tidak miring ke kiri atau pun miring ke kanan dengan nilai tengah pada angka 0 dan standar deviasi sebesar 0.970 mendekati angka 1 .

Berikut gambar 5.2 mengenai grafik normal plot:

Gambar 5.2 Grafik Normal Plot

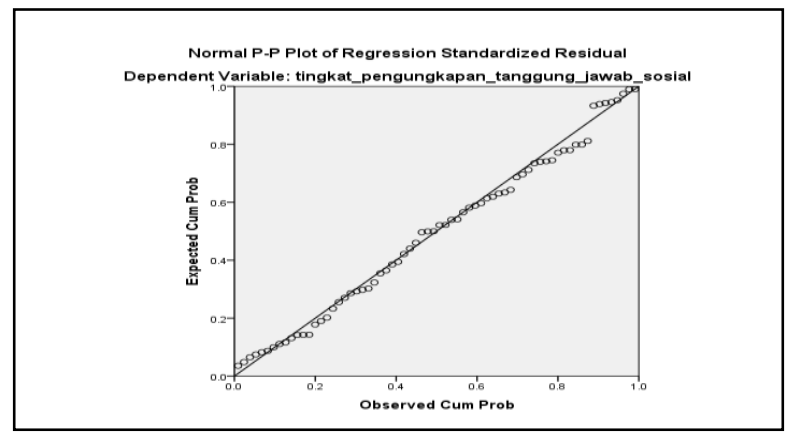


Sumber: Output SPSS, Hasil Olah Data 2018

Dari gambar 5.2 grafik normal plot di atas dapat dilihat titik-titik menyebar tidak terlalu jauh dari sekitar garis diagonal atau grafik histogramnya dan mengikuti arah garis diagonal. Garis diagonal juga menunjukkan satu pola yang tidak miring ke arah kanan atau pun arah kiri dengan demikian data residual ini terdistribusi dengan normal.

Berikut tabel 5.4 mengenai uji Kolmogorov-Smirnov:

Tabel 5.4 Uji Kolmogorov-Smirnov

One-Sample Kolmogorov-Smirnov Test

\begin{tabular}{|ll|r|}
\hline & & Unstandardized Residual \\
\hline Normal Parameters & & 68 \\
& Mean & .0000000 \\
& Std. Deviation & .12147001 \\
Most Extreme Differences & Absolute & .064 \\
& Positive & .064 \\
Kolmogorov-Smirnov Z & Negative & -.056 \\
Asymp. Sig. (2-tailed) & & .525 \\
a. Test distribution is Normal. & .945 \\
\hline
\end{tabular}

b. Calculated from data.

Sumber: Output SPSS, Hasil Olah Data 2018

Dengan melihat tabel 5.4 hasil uji Kolmogorov-Smirnov di atas, dapat diketahui nilai uji Kolmogorov-Smirnov yang diperoleh adalah 0.525 dengan nilai signifikansi data adalah 0.945 lebih besar dari $0.05(0.945>0.05)$ maka hipotesis Ho dapat diterima. Dengan demikian dapat disimpulkan bahwa data residual terdistribusi normal. Dari ketiga hasil uji normalitas data diperoleh residual terdistribusi normal sehingga model regresi sudah memenuhi asumsi normalitas dan sudat tepat digunakan.

\section{Uji Multikolinearitas}

Berikut tabel 5.5 mengenai coefficients untuk melihat uji multikolinieritas:

\section{Tabel 5.5 Coefficients}

\begin{tabular}{|c|c|c|c|}
\hline \multirow{2}{*}{\multicolumn{2}{|c|}{ Model }} & \multicolumn{2}{|c|}{ Collinearity Statistics } \\
\hline & & Tolerance & VIF \\
\hline \multirow{5}{*}{1} & (Constant) & & \\
\hline & komisaris_independen & .914 & 1.094 \\
\hline & dewan_pengawas_syariah & .956 & 1.046 \\
\hline & kepemilikan_institusional & .930 & 1.076 \\
\hline & profitabilitas & .962 & 1.040 \\
\hline
\end{tabular}

a. Dependent Variable: tingkat_pengungkapan_tanggung_jawab_sosial

Sumber: Output SPSS, Hasil Olah Data 2018

Hasil pengujian nilai tolerance dalam tabel 5.5 coefficients di atas menunjukkan nilai variabel independen yaitu komisaris independen sebesar 0.914, dewan pengawas syariah (DPS) sebesar 0.956, kepemilikan institusional sebesar 0.930 dan profitabilitas sebesar 0.962. Dapat dilihat semua hasil nilai uji variabel independen menunjukkan nilai tolerance lebih dari 0.10 yang artinya tidak ada korelasi antar variabel independen.

Hasil pengujian nilai variance inflation factor (VIF) menunjukkan variabel independen yaitu komisaris independen sebesar 1.094, dewan pengawas syariah sebesar 1.046, kepemilikan institusional sebesar 1.076, dan profitabilitas sebesar 1.040. Dapat dilihat hasil perhitungan VIF tidak ada yang menunjukkan satu variabel independen yang memiliki nilai VIF lebih dari 10. Dengan demikian dapat disimpulkan bahwa tidak ada multikolinieritas antar variabel independen dalam model regresi. 


\section{Uji Autokorelasi}

Berikut tabel 5.6 mengenai model summary untuk melihat hasil uji DW:

Tabel 5.6 Model Summary ${ }^{b}$

\begin{tabular}{|l|r|r|r|r|r|}
\hline Model & \multicolumn{1}{|c|}{ R } & R Square & $\begin{array}{c}\text { Adjusted R } \\
\text { Square }\end{array}$ & $\begin{array}{c}\text { Std. Error of the } \\
\text { Estimate }\end{array}$ & Durbin-Watson \\
\hline 1 & $.432^{\mathrm{a}}$ & .186 & .135 & .1252669 & 2.237 \\
\hline
\end{tabular}

Sumber: Output SPSS, Hasil Olah Data 2018

Menggunakan keputusan menurut Priyatno (2014:106), du $<\mathrm{dw}<4-$ du maka diperoleh nilai uji $1.7335<2.237<2.2665$ yang dapat diartikan nilai uji du (1.7335) lebih kecil dari nilai Durbin Watson (2.237) dan nilai Durbin Watson tersebut lebih kecil dari nilai $4-\mathrm{du}(4-1.7335=2.2665)$. Dengan demikian hipotesis Ho diterima artinya tidak terjadi autokorelasi.

\section{Uji Heteroskedastisitas}

Berikut gambar 5.3 mengenai scatterplot:

\section{Gambar 5.3 Scatterplot}

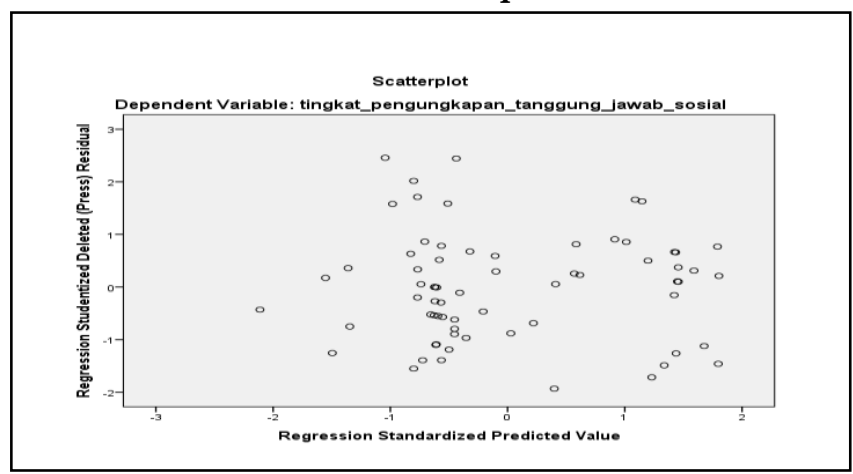

Sumber: Output SPSS, Hasil Olah Data 2018

Berdasarkan gambar 5.3 scatterplot di atas dapat dianalisis titik-titik menyebar dengan pola yang tidak jelas atau tidak membentuk pola yang teratur di atas dan di bawah angka 0 pada sumbu $\mathrm{Y}$. Dengan demikian dapat disimpulkan bahwa model regresi penelitian ini tidak terjadi masalah heteroskedastisitas.

\section{Pengujian Hipotesis}

Pengujian hipotesis dalam penelitian ini menggunakan teknik analisis regresi linier berganda (multiple linear regression) dengan bantuan SPSS 21. Berikut tabel 5.7 mengenai hasil analisis regresi berganda dengan melihat coefficients:

\section{Tabel 5.7 Hasil Analisis Regresi Berganda}

\section{Coefficients}

\begin{tabular}{|c|c|c|c|c|c|c|}
\hline \multirow{2}{*}{\multicolumn{2}{|c|}{ Model }} & \multicolumn{2}{|c|}{$\begin{array}{l}\text { Unstandardized } \\
\text { Coefficients }\end{array}$} & \multirow{2}{*}{$\begin{array}{c}\begin{array}{c}\text { Standardize } \\
\mathbf{d} \\
\text { Coefficients }\end{array} \\
\text { Beta }\end{array}$} & \multirow[t]{2}{*}{$\mathbf{t}$} & \multirow[t]{2}{*}{ Sig. } \\
\hline & & B & $\begin{array}{c}\text { Std. } \\
\text { Error }\end{array}$ & & & \\
\hline \multirow{5}{*}{1} & (Constant) & .178 & .152 & & 1.168 & .247 \\
\hline & komisaris_independen & -.139 & .097 & -.171 & -1.443 & .154 \\
\hline & dewan_pengawas_syariah & .107 & .032 & .395 & 3.399 & .001 \\
\hline & kepemilikan_institusional & .016 & .137 & .014 & .117 & .907 \\
\hline & profitabilitas & -2.112 & 1.700 & -.144 & -1.242 & 219 \\
\hline
\end{tabular}

a. Dependent Variable: tingkat_pengungkapan_tanggung_jawab_sosial

Sumber: Output SPSS, Hasil Olah Data 2018

Berdasarkan tabel 5.7 mengenai coefficients, dapat dibuat persamaan analisis regresi linier berganda sebagai berikut:

$$
Y=0.178-0.139 X_{1}+0.107 X_{2}+0.016 X_{3}-2.112 X_{4}+e
$$




\section{Uji Statistik t}

\section{Pengujian Hipotesis $\mathrm{Ha}_{1}$}

Hasil uji hipotesis $1\left(\mathrm{Ha}_{1}\right)$ yaitu komisaris independen $\left(\mathrm{X}_{1}\right)$ dalam penelitian ini memiliki hasil uji nilai koefisien $\left(\beta_{1}\right)$ adalah bertanda negatif sebesar -0.139 . Melihat nilai $t_{\text {hitung }}$ dan $t_{\text {tabel }}$ menunjukkan nilai uji $\mathrm{t}_{\text {hitung }}-1.443$ lebih kecil dari $\mathrm{t}_{\text {tabel }} 1.669\left(\mathrm{t}_{\text {hitung }}-1.443<\mathrm{t}_{\text {tabel }} 1.669\right)$ artinya tidak berpengaruh. Jika melihat tingkat signifikansi diperoleh nilai uji sebesar 0.154 lebih besar dari signifikansi 0.05 (nilai uji signifikan $0.154>$ sig 0.05) yang artinya tidak berpengaruh. Ini memberikan arti bahwa komisaris independen tidak berpengaruh terhadap tingkat pengungkapan tanggung jawab sosial. Dengan demikian, hipotesis 1 yang menyatakan bahwa komposisi komisaris independen berpengaruh positif dan signifikan terhadap tingkat pengungkapan tanggung jawab sosial tidak dapat diterima atau ditolak.

\section{Pengujian Hipotesis $\mathrm{Ha}_{2}$}

Hasil uji hipotesis $2\left(\mathrm{Ha}_{2}\right)$ yaitu Dewan Pengawas Syariah (DPS) $\left(\mathrm{X}_{2}\right)$ memiliki hasil uji nilai koefisien $\left(\beta_{2}\right)$ adalah bertanda positif sebesar 0.107 . Melihat nilai $t_{\text {hitung }}$ dan $t_{\text {tabel }}$ menunjukkan nilai uji $\mathrm{t}_{\text {hitung }} 3.399$ lebih besar dari $\mathrm{t}_{\text {tabel }} 1.669\left(\mathrm{t}_{\text {hitung }} 3.399>\mathrm{t}_{\text {tabel }}\right.$ 1.669) yang artinya berpengaruh. Jika melihat taraf signifikansinya diperoleh nilai uji sebesar 0.001 lebih kecil dari signifikansi 0.05 (nilai uji signifikan $0.001<$ sig 0.05 ) yang artinya berpengaruh.

\section{Pengujian Hipotesis $\mathrm{Ha}_{3}$}

Hasil uji hipotesis $3\left(\mathrm{Ha}_{3}\right)$ yaitu kepemilikan institusional $\left(\mathrm{X}_{3}\right)$ memiliki hasil uji nilai koefisien $\left(\beta_{3}\right)$ adalah bertanda positif sebesar 0.016. Melihat nilai $t_{\text {hitung }}$ dan $t_{\text {tabel }}$ menunjukkan nilai uji $t_{\text {hitung }}$ 0.117 lebih kecil dari $\mathrm{t}_{\text {tabel }} 1.669\left(\mathrm{t}_{\text {hitung }} 0.117<\mathrm{t}_{\text {tabel }} 1.669\right)$ yang artinya tidak berpengaruh. Jika melihat tingkat signifikansinya diperoleh nilai uji sebesar 0.907 lebih besar dari signifikansi 0.05 (nilai uji signifikan $0.907>$ sig 0.05 ) yang artinya tidak berpengaruh. Hasil ini memberikan arti bahwa kepemilikan institusional tidak berpengaruh terhadap tingkat pengungkapan tanggung jawab sosial. Dengan demikian hipotesis 3 yang menyatakan bahwa kepemilikan institusional berpengaruh positif dan signifikan terhadap tingkat pengungkapan tanggung jawab sosial tidak dapat diterima atau ditolak.

\section{Pengujian Hipotesis $\mathrm{Ha}_{4}$}

Hasil uji hipotesis $4\left(\mathrm{Ha}_{4}\right)$ yaitu profitabilitas $\left(\mathrm{X}_{4}\right)$ memiliki hasil uji nilai koefisien $\left(\beta_{4}\right)$ adalah bertanda negatif sebesar -2.112. Melihat nilai $t_{\text {hitung }}$ dan $t_{\text {tabel }}$ menunjukkan nilai uji $t_{\text {hitung }}-1.242$ lebih kecil dari $\mathrm{t}_{\text {tabel }} 1.669\left(\mathrm{t}_{\text {hitung }}-1.242<\mathrm{t}_{\text {tabel }} 1.669\right)$ yang artinya tidak berpengaruh. Jika melihat tingkat signifikansi diperoleh nilai uji sebesar 0.219 lebih besar dari signifikansi 0.05 (nilai uji signifikan $0.219>$ sig 0.05 ) yang artinya tidak berpengaruh. Hasil ini memberikan arti bahwa profitabilitas tidak berpengaruh terhadap tingkat pengungkapan tanggung jawab sosial. Dengan demikian hipotesis 4 yang menyatakan bahwa profitabilitas berpengaruh positif dan signifikan terhadap tingkat pengungkapan tanggung jawab sosial tidak dapat diterima atau ditolak.

\section{Uji Statistik F}

Hasil uji statistik F dapat dilihat pada hasil uji Anova (analysis of variance) dalam tabel 5.8 berikut ini:

Tabel 5.8 Hasil Uji Anova a atau F test

\begin{tabular}{|rl|r|r|r|r|r|}
\hline Model & Sum of Squares & \multicolumn{1}{c|}{ df } & Mean Square & \multicolumn{1}{c|}{ F } & Sig. \\
\hline \multirow{2}{*}{1} & Regression & .226 & 4 & .057 & 3.607 & $.010^{\mathrm{b}}$ \\
& Residual & .989 & 63 & .016 & & \\
& Total & 1.215 & 67 & & & \\
\hline
\end{tabular}

Sumber: Output SPSS, Hasil Olah Data 2018

Berdasarkan tabel 5.8 hasil uji Anova di atas, dapat diambil keputusan dengan melihat nilai $\mathrm{F}_{\text {hitung }}$ dan $\mathrm{F}_{\text {tabel }}$ serta nilai signifikansi 0.05 . Hasil uji diperoleh nilai uji $\mathrm{F}_{\text {hitung }} 3.607$ lebih besar dari nilai $\mathrm{F}_{\text {tabel }} 2.518\left(\mathrm{~F}_{\text {hitung }} 3.607>\mathrm{F}_{\text {tabel }} 2.518\right)$ yang artinya berpengaruh. Jika melihat tingkat signifikansinya diperoleh nilai uji sebesar $0.010^{\mathrm{b}}$ yang nilainya lebih kecil dari 0.05 (nilai uji signifikan $0.010<0.05$ ) yang dapat diartikan berpengaruh. Dengan demikian variabel independen yang terdiri dari komisaris independen, dewan pengawas syariah, kepemilikan institusional, dan 
profitabilitas secara simultan atau bersama-sama berpengaruh terhadap tingkat pengungkapan tanggung jawab sosial.

Uji Koefisien Determinasi $\left(\mathbf{R}^{2}\right)$

Hasil uji koefisien determinasi $\left(\mathrm{R}^{2}\right)$ dapat dilihat dalam tabel 5.9 berikut ini:

Tabel 5.9 Model Summary ${ }^{b}$

\begin{tabular}{|l|r|r|r|r|}
\hline Model & R & R Square & $\begin{array}{c}\text { Adjusted R } \\
\text { Square }\end{array}$ & $\begin{array}{c}\text { Std. Error of the } \\
\text { Estimate }\end{array}$ \\
\hline 1 & $.432^{\mathrm{a}}$ & .186 & .135 & .1252669 \\
\hline
\end{tabular}

Sumber: Output SPSS, Hasil Olah Data 2018

Berdasarkan tabel 5.9 hasil koefisien determinasi $\left(\mathrm{R}^{2}\right)$ menunjukkan bahwa nilai Adjusted $\mathrm{R}$ Square sebesar $0.135(13.5 \%)$. Hal tersebut menunjukkan bahwa besarnya pengaruh komisaris independen $\left(\mathrm{X}_{1}\right)$, dewan pengawas syariah $\left(\mathrm{X}_{2}\right)$, kepemilikan institusional $\left(\mathrm{X}_{3}\right)$ dan profitabilitas $\left(\mathrm{X}_{4}\right)$ terhadap tingkat pengungkapan tanggung jawab sosial (Y) bank umum syariah (BUS) di Indonesia adalah sebesar $13.5 \%$ sedangkan sisanya sebesar $86.5 \%$ (100-13.5) dipengaruhi oleh variabel independen lain yang tidak dimasukkan dalam penelitian ini. Koefisien determinasi $\left(\mathrm{R}^{2}\right)$ dalam penelitian ini rendah karena pengumpulan data adalah menggunakan cross section (data silang).

\section{Pembahasan}

\section{Pengaruh Komisaris Independen Terhadap Tingkat Pengungkapan Tanggung Jawab Sosial}

Hipotesis 1 yang menyatakan bahwa komposisi komisaris independen berpengaruh positif dan signifikan terhadap tingkat pengungkapan tanggung jawab sosial tidak dapat diterima atau ditolak. Hasil uji ini memberikan interpretasi bahwa besarnya komposisi komisaris independen tidak dapat mempengaruhi pengawasan yang dilakukan oleh dewan komisaris terhadap kinerja manajemen dalam hal ini pihak direksi sehingga tidak berpengaruh terhadap tingkat pengungkapan tanggung jawab sosial.

Berdasarkan pengertiannya dalam peraturan Otoritas Jasa Keuangan nomor 55 tahun 2016 tentang penerapan tata kelola bagi bank umum bab I mengenai ketentuan umum dalam bab III mengenai dewan komisaris bagian 1 tentang jumlah, komposisi, kriteria, dan independensi dewan komisaris dalam pasal 24 ayat 2 menyatakan bahwa komisaris independen wajib paling sedikit berjumlah 50\% dari jumlah anggota dewan komisaris. Seharusnya, komposisi keanggotaan dewan, dalam hal ini semakin besar persentase anggota yang berasal dari luar perusahaan (komisaris independen) akan menjadikan peranan dewan komisaris semakin efektif dalam melaksanakan fungsi pengawasan terhadap pengelolaan perusahaan, karena dianggap semakin independen (Nuryaman, 2009).Sedangkan menurut pengertiannya menurut peraturan yang sama dalam pasal 4 yang dimaksud dengan komisaris independen adalah anggota dewan komisaris yang tidak memiliki hubungan keuangan, kepengurusan, kepemilikan saham dan/atau hubungan keluarga dengan anggota direksi, anggota dewan komisaris lain dan/atau pemegang saham pengendali, atau hubungan dengan bank yang dapat mempengaruhi kemampuan yang bersangkutan untuk bertindak independen. Berdasarkan pengertian tersebut dapat diduga komisaris independen belum mampu menjalankan fungsi dan perannya sehingga tidak berpengaruh terhadap tingkat pengungkapan tanggung jawab sosial. Dengan demikian dapat diduga komisaris independen dalam penelitian ini hanya bersifat formalitas untuk memenuhi tata aturan tersebut.

Hasil penelitian ini tidak mendukung teori agensi, dimana teori agensi menyatakan dewan komisaris yang berasal dari luar perusahaan (independen) akan dipandang lebih baik karena mereka akan menetapkan kebijakan yang berkaitan dengan perusahaan secara lebih obyektif dibanding perusahaan yang memiliki susunan dewan komisaris yang hanya berasal dari dalam perusahaan (Sulistyawati et al, 2016). Posisi komisaris independen sebagai pihak principal yang mewakili pihak pemegang saham atau pun pihak stakeholders belum mampu mengawasi kinerja dari pihak agent (manajemen) berkaitan dengan peningkatan pengungkapan tanggung jawab sosial. Hasil penelitian ini juga tidak mendukung teori legitimasi. Seharusnya pihak komisaris independen bisa memberikan nasihat, tekanan dan mendorong pihak manajemen untuk melakukan aktivitas berkaitan dengan peningkatan pengungkapan tanggung jawab sosial dalam laporan tahunan sebagai pemenuhan aturan 
yang sudah ditetapkan dengan tujuan mendapatkan status atau pun legalitas dan pengakuan dari masyarakat, pemerintah, individu atau pun kelompok masyarakat.

Hasil penelitian ini sejalan dengan hasil penelitian Farida et al (2010) meneliti mengenai pengaruh penerapan corporate governance terhadap timbulnya earning management dalam menilai kinerja keuangan pada perusahaan perbankan di Indonesia periode 2005 sampai 2007. Hasil penelitian ini juga sejalan dengan hasil penelitian Lestari (2013) meneliti mengenai faktor penentu dari Islamic social reporting (ISR) pada 18 laporan tahunan dari 10 bank umum syariah di Indonesia periode 20102011 yang menghasilkan uji yang sama dimana proporsi komisaris independen tidak signifikan mempengaruhi level dari pengungkapan Islamic social reporting.

\section{Pengaruh Dewan Pengawas Syariah Terhadap Tingkat Pengungkapan Tanggung Jawab Sosial}

Hipotesis 2 yang menyatakan bahwa dewan pengawas syariah berpengaruh positif dan signifikan terhadap tingkat pengungkapan tanggung jawab sosial dapat diterima. Hasil uji ini memberikan interpretasi bahwa semakin banyak jumlah dewan pengawas syariah akan meningkatkan pengungkapan tanggung jawab sosial karena kemampuan jumlah anggota dewan pengawas syariah dalam melakukan tugas dan fungsinya yaitu mengontrol dan memantau aktivitas bank bank umum syariah (BUS) berdasar prinsip syariah jauh lebih efektif dan efisien dengan semakin banyaknya jumlah anggota dewan pengawas syariah.

Jumlah dewan pengawas syariah dalam penelitian ini membuktikan bahwa banyaknya jumlah dewan pengawas syariah bukan hanya sebagai pemenuhan formalitas yang berlaku ditetapkan yaitu berdasar pada peraturan bank Indonesia nomor 11 tahun 2009 tentang bank umum syariah dalam bab IV pasal 36 ayat 1 yang menyatakan jumlah dewan pengawas syariah paling kurang 2 orang atau paling banyak 50\% dari jumlah anggota direksi. Dengan semakin banyaknya jumlah dewan pengawas syariah mampu melakukan pengawasan yang efektif terhadap kinerja manajemen dalam hal ini pihak direksi berdasarkan prinsip syariah sehingga berdampak pada pengungkapan tanggung jawab sosial yang meningkat.

Dewan pengawas syariah mendukung teori syariah enterprise theory ini dimana jumlah dewan pengawas syariah mampu mengontrol kinerja pihak direksi sehingga terjadi peningkatan pengungkapan tanggung jawab sosial dalam laporan tahunan. Hasil uji dewan pengawas syariah juga mendukung teori legitimasi dimana dewan pengawas syariah mampu mengontrol kinerja pihak direksi untuk berpihak khususnya pada umat dengan melakukan peningkatan pengungkapan tanggung jawab sosial sehingga kepercayaan dari kelompok umat semakin tinggi yang berpengaruh pada eksistensi bank umum syariah itu sendiri.

Hasil penelitian ini sejalan dan mendukung hasil penelitian yang dilakukan oleh Inuzula (2017) yang meneliti mengenai pengungkapan Islamic social reporting pada bank umum syariah di Indonesia periode 2011-2013 dengan menggunakan tingkat signifikansi 0.05 dan indikator pengukuran berdasarkan ukuran atau jumlah dewan pengawas syariah. Hasil penelitian ini juga sejalan dengan penelitian Ningrum et al (2013) yang meneliti mengenai pengaruh kinerja keuangan, kepemilikan institusional, dan ukuran dewan pengawas syariah terhadap pengungkapan Islamic social reporting (ISR) pada 24 pengamatan perbankan syariah pada tahun 2010-2012.

\section{Pengaruh Kepemilikan Institusional Terhadap Tingkat Pengungkapan Tanggung Jawab Sosial}

Hipotesis 3 yang menyatakan bahwa kepemilikan institusional berpengaruh positif dan signifikan terhadap tingkat pengungkapan tanggung jawab sosial tidak dapat diterima atau ditolak. Hasil uji ini memberikan interpretasi bahwa besarnya komposisi kepemilikan saham oleh institusi tidak berpengaruh terhadap tingkat pengungkapan tanggung jawab sosial. Tidak berpengaruh ini mengartikan bahwa komposisi kepemilikan saham institusi yang besar tidak mampu memonitoring atau memantau kinerja manajemen dalam hal ini pihak direksi dalam hal meningkatkan pengungkapan tanggung jawab sosial.

Hasil penelitian ini tidak mendukung teori stakeholder dimana tujuan dari teori stakeholders adalah untuk menolong manajer korporasi dalam meningkatkan nilai dari dampak aktifitas-aktifitas mereka, dan meminimalkan kerugian-kerugian bagi stakeholder (Yuniarti, 2007). Stakeholder theory menyatakan bahwa stakeholder merupakan pihak yang berkepentingan terhadap perusahaan yang dapat stakeholder mempengaruhi atau dapat dipengaruhi oleh aktivitas perusahaan (Rawi, 2008). Ini bisa disebabkan pemegang saham institusi dapat mengakses secara langsung informasi dalam laporan 
tahunan sehingga pemegang saham institusi kurang tertarik untuk membantu atau menolong kinerja pihak direksi dalam hal peningkatan pengungkapan tanggung jawab sosial guna memberikan manfaat kepada stakeholders. Hasil penelitian yang tidak berpengaruh ini mengartikan bahwa hasil penelitian ini tidak mendukung teori agensi dengan dugaan, pemilik saham institusi sudah melakukan monitoring dan mengotrol kinerja manajemen secara efektif terutama pada peningkatan tanggung jawab sosial akan tetapi sebagai pengambil keputusan adalah pada pihak manajemen yaitu pihak direksi.

Hasil penelitian ini sejalan dengan hasil penelitian Ritha (2016) yang meneliti mengenai pengaruh struktur kepemilikan dan ukuran (size) perbankan terhadap kinerja 6 perbankan di Indonesia yang terdaftar di Bursa Efek Indonesia periode 2009 sampai 2014. Hasil tidak berpengaruh tersebut diduga relatif kecilnya porsi kepemilikan institusi perbankan meskipun tidak semua saham perbankan dimiliki oleh institusi (bank, asuransi, perusahaan investasi, perusahaan efek, dana pensiun, dan lainlain) dapat menyebabkan terbatasnya kesempatan pihak institusi untuk memonitor manajemen dalam operasional perbankan.

\section{Pengaruh Profitabilitas Terhadap Tingkat Pengungkapan Tanggung Jawab Sosial}

Hipotesis 4 yang menyatakan bahwa profitabilitas berpengaruh positif dan signifikan terhadap tingkat pengungkapan tanggung jawab sosial tidak dapat diterima atau ditolak. Hasil uji ini memberikan interpretasi bahwa menurunnya profitabilitas yang diperoleh tidak berpengaruh terhadap tingkat pengungkapan tanggung jawab sosial.

Hasil penelitian ini menunjukkan bahwa tidak berpengaruhnya profitabiltias terhadap tingkat pengungkapan tanggung jawab sosial dapat diduga dikarenakan menurunnya perolehan profit yang ditandai dengan tanda negatif. Menurunnya profitabilitas ini membuat bank umum syariah tidak dapat berbuat banyak dalam peningkatan pengungkapan tanggung jawab sosial kepada stakeholders diantaranya karyawan, umat, pemerintah dan lingkungan.

Hasil penelitian ini tidak mendukung syariah enterprise theory. Meskipun bank umum syariah sebagai perusahaan yang berbasis syariah mendapatkan laba atau pun rugi tetap harus memberikan pengungkapan tanggung jawab sosial secara luas di dalam laporan tahunan. Dijelaskan dalam firman Tuhan (Al-Qur'an, 2:42) yang artinya janganlah kamu campur adukkan yang hak dengan yang bathil dan janganlah kamu sembunyikan yang hak itu, sedang kamu mengetahui." Secara tidak langsung firman Tuhan ini memerintahkan dalam hal ini bank umum syariah untuk melakukan pengungkapan tanggung jawab sosial dengan jujur meskipun profitabilitas yang diperoleh menurun karena dana untuk melakukan pengungkapan tanggung jawab sosial bukan hanya dari profitabilitas melainkan dapat berasal dari dana zakat, infak, sedekah, atau pun wakaf.

Hasil penelitian ini juga tidak mendukung teori stakeholders. Teori stakeholders menyatakan perusahaan bukanlah entitas yang hanya beroperasi untuk kepentingan sendiri namun harus mampu memberikan manfaat bagi stakeholdersnya (Sulistyawati dan Yuliani, 2017). Pengungkapan sebagai komitmen perusahaan yang kegiatan operasinya berdasarkan prinsip syariah serta sebagai pelaksanaan visi perbankan syariah yaitu mencapai kemaslahatan (manfaat) masyarakat. Perolehan profitabilitas yang meningkat atau pun menurun seharusnya berpengaruh terhadap peningkatan pengungkapan tanggung jawab sosial karena perusahaan harus memberikan manfaat kepada stakeholders.

Penelitian yang dilakukan oleh Setiawan et al (2016) mengenai tingkat pelaksanaan dan pelaporan Islamic social reporting pada perbankan syariah di Indonesia menggunakan return on assets juga menghasilkan uji yang sama. Menurut Setiawan et al (2016) hal tersebut bisa jadi karena dana yang digunakan dalam pelaksanaan tanggung jawab sosial yang dilaksanakan oleh bank syariah bukan berasal dari profit yang diperoleh bank syariah, namun berasal dari dana zakat, infaq, sadaqah maupun pendapatan non-halal. Hasil penelitian ini juga sejalan dengan hasil penelitian Sulistyawati dan Yuliani (2017) yang meneliti mengenai pengungkapan Islamic social reporting pada 39 perusahaan yang termasuk dalam indeks saham syariah Indonesia periode 2012 sampai 2014. Tidak adanya pengaruh yang signifikan ini mengindikasikan bahwa tinggi rendahnya profitabilitas tidak berdampak pada pengungkapan Islamic social reporting di perusahaan. Hal ini disebabkan karena perusahaan yang memiliki profitabilitas yang tinggi belum tentu banyak melakukan aktivitas sosial karena perusahaan lebih berorientasi pada laba semata. Sedangkan pada saat perusahaan memperoleh laba yang rendah maka terdapat persepsi bahwa pengguna laporan keuangan senang untuk membaca berita baik tentang kinerja perusahaan dalam bidang sosial. 


\section{Penutup}

\section{Kesimpulan}

Berdasarkan hasil pengujian hipotesis yang dilakukan, maka dapat dibuat kesimpulan sebagai berikut:

1. Hasil pengujian hipotesis 1 menunjukkan bahwa komisaris independen tidak berpengaruh terhadap tingkat pengungkapan tanggung jawab sosial bank syariah. Implikasinya adalah komisaris independen yang diukur menggunakan komposisi komisaris independen tidak dapat mempengaruhi pengawasan dan monitoring terhadap kinerja manajemen yaitu pihak direksi dalam pengambilan keputusan salah satunya berkaitan dengan tingkat pengungkapan tanggung jawab sosial. Alasannya adalah kemungkinan komisaris independen hanya sebagai formalitas dalam pemenuhan aturan yang berlaku. Kemungkinan lain yang dapat diduga adalah adanya penempatan komisaris independen yang tidak sesuai dengan kapasitas kompetensi dan pengalaman dalam bidang tugasnya. Dugaan berikutnya kemungkinan komisaris independen melakukan pengawasan dan monitoring secara efektif atau pun tidak efektif tidak berpengaruh karena komisaris independen bukan sebagai pihak yang mengambil keputusan berkaitan dengan peningkatan pengungkapan tanggung jawab sosial.

2. Hasil pengujian hipotesis 2 menunjukkan bahwa dewan pengawas syariah berpengaruh terhadap tingkat pengungkapan tanggung jawab sosial bank syariah. Implikasinya adalah dewan pengawas syariah yang diukur menggunakan jumlah anggota dari dewan pengawas mampu memberikan pengawasan terhadap kinerja pihak manajemen dalam hal ini pihak direksi. Semakin banyak jumlah anggota dewan pengawas syariah akan meningkatkan pengungkapan tanggung jawab sosial karena kemampuan jumlah anggota dewan pengawas syariah dalam melakukan tugas dan fungsinya yaitu mengontrol dan memantau aktivitas bank bank umum syariah berdasar prinsip syariah jauh lebih efektif dan efisien dengan semakin banyaknya jumlah anggota dewan pengawas syariah.

3. Hasil pengujian hipotesis 3 menunjukkan bahwa kepemilikan institusional tidak berpengaruh terhadap tingkat pengungkapan tanggung jawab sosial bank syariah. Implikasinya adalah kepemilikan institusional yang diukur menggunakan komposisi kepemilikan institusional tidak dapat memberikan pengawasan terhadap kinerja pihak manajemen dalam hal ini pihak direksi. Tidak berpengaruh ini mengartikan bahwa komposisi kepemilikan saham institusi yang besar tidak mampu memonitoring atau memantau kinerja manajemen dalam hal ini pihak direksi dalam hal meningkatkan pengungkapan tanggung jawab sosial dengan dugaan, pemilik saham institusi sudah melakukan monitoring dan mengotrol kinerja manajemen secara efektif terutama pada peningkatan tanggung jawab sosial akan tetapi sebagai pengambil keputusan adalah pada pihak direksi.

4. Hasil pengujian hipotesis 4 menunjukkan bahwa profitabilitas tidak berpengaruh terhadap tingkat pengungkapan tanggung jawab sosial bank syariah. Implikasinya adalah profitabilitas yang diukur menggunakan return on assets (ROA) tidak dapat mempengaruhi tingkat pengungkapan tanggung jawab sosial. Menurunnya profitabilitas yang diperoleh tidak berpengaruh terhadap tingkat pengungkapan tanggung jawab sosial. Menurunnya profitabilitas ini membuat bank umum syariah tidak dapat berbuat banyak dalam peningkatan pengungkapan tanggung jawab sosial kepada stakeholders diantaranya karyawan, umat, pemerintah dan lingkungan.

\section{Saran}

lain:

Berdasarkan hasil penelitian yang sudah dilakukan, maka saran yang dapat diberikan antara

1. Bagi pihak manajemen bank umum syariah diharapkan untuk lebih meningkatkan pengungkapan tanggung jawab sosial.

2. Bagi pemerintah dan Ikatan Akuntansi Indonesia (IAI) dapat membuat suatu standar mengenai pengungkapan tanggung jawab sosial.

3. Hasil uji nilai Adjusted $\mathrm{R}^{2}$ yang diperoleh sangat rendah yaitu 0.135 atau 13.5 artinya ada pengaruh lebih besar terhadap tingkat pengungkapan tanggung jawab sosial dari variabel independen lain yang tidak diteliti dalam penelitian ini sehingga bagi penulis selanjutnya dapat dilakukan pengujian dengan memasukkan variabel independen lain. 


\section{Daftar Pustaka}

Al-Qur'an dan Terjemahannya. 1990. Yayasan Penyelenggaraan Penterjemah/Penafsir Al-Qur'an

Aribi, Zakaria Ali dan Simon Gao. 2010. Corporate Social Responsibility Disclosure A Comparison Between Islamic And Conventional Financial Institutions. Journal Of Financial Reporting And Accounting. pp.72-91. Vol (8) No. 2.

Dewi, Sisca C. 2008. Pengaruh Kepemilikan Managerial, Kepemilikan Institusional, Kebijakan Hutang, Profitabilitas Dan Ukuran Perusahaan Terhadap Kebijakan Deviden. Jurnal Bisnis dan Akuntansi. April. 47-58. Vol (10) No 1.

Fahmi, Irfan. 2014. Pengantar Perbankan Teori \& Aplikasi. Cetakan Kesatu. $\quad$ Bandung: Alfabeta

Farida, Y., Nur, Yuli Prasetyo, dan E., Herwiyanti. 2010. Pengaruh Penerapan Corporate Governance Terhadap Timbulnya Earnings Management Dalam Menilai Kinerja Keuangan Pada Perusahaan Perbankan Di Indonesia. Jurnal Bisnis Dan Akuntansi. Hlm. 69-80. Agustus. Vol (12) No. 2.

Gustani. 2013. Model Pelaporan Kinerja Sosial Perbankan Syariah: Implementasi Islamic Social Reporting Indeks (Indeks ISR) Di Indonesia. Jurnal Akuntansi Dan Keuangan Islam I. No. 2.

Hackston, David dan Markus J., Milne. 1996. Some Determinants Of Social And Environmental Disclosure In New Zealand Companies. Accounting, Auditing \& Accountability Journal. pp 77-108. Vol (9) No.1.

Haniffa, Roszaini dan Mohammad Hudaib. 2007. Exploring The Ethical Identity Of Islamic Bank Via Communication In Annual Reports. Journal Of Business Ethics. 76:97-116.

Harahap, S., Syafri. 2012. Teori Akuntansi. Cetakan Ke-12. Jakarta: PT. RajaGrafindo Persada.

Harmono. 2016. Manajemen Keuangan Berbasis Balanced Scorecard Pendekatan Teori, Kasus, Dan Riset Bisnis. Cetakan Kelima. Jakarta: Bumi Aksara.

Hassan, Abdul dan Sofyan S., Harahap. 2010. Exploring Corporate Social Responsibility Disclosure: The Case Of Islamic Banks. International Journal Of Islamic And Middle Eastern Finance And Management. pp. 203-227. Vol (3) No.3.

Inuzula, Lakharis. 2017. Pengaruh Size, Profitabilitas, Dan Dewan Pengawas Syariah Terhadap Pengungkapan Islamic Social Reporting Pada Bank Umum Syariah Di Indonesia. Jurnal Kebangsaan. Januari-Juni.Vol. (6) No.11.

Istighfarin, Diana, dan Ni Gusti Putu Wirawati. 2015. Pengaruh Good Corporate Governance Terhadap Profitabilita Pada Badan Usaha Milik Negara (BUMN). Hal. 564-581. November. Vol (13) No. 2.

Kasmir. 2011. Analisa Laporan Keuangan. Cetakan Ke-4. Jakarta: PT. RajaGrafindo Persada.

Lestari, Puji. 2013. Determinants Of Islamic Social Reporting In Syariah Banks:Case Of Indonesia. International Journal of Busniness and Management Invention. October. 28-34. Volume (2).

Libby, Robert P., A., Libby, dan Daniel G., Short. 2008. Akuntansi Keuangan. Edisi Kelima. Yogyakarta: ANDI.

Maali, Bassam P., Casson dan C., Napier. 2006. Social Reporting by Islamic Banks.Accounting Foundation. The University of Sydney. Vol. (42) No. 2.

Maksum, Azhar. 2005. Tinjauan Atas Good Corporate Governance Di Indonesia. Pidato Pengukuhan Jabatan Guru Besar Tetap Universitas Sumatera Utara Medan.

Mariana, M. (2016). Pengaruh Mekanisme Corporate Governance Terhadap Peringkat Obligasi Yang Tercatat Di Bursa Efek Indonesia Periode Tahun 2008-2010. Akrual: Jurnal Akuntansi. 104-132. 7(2).

Murwaningsari, Etty. (2009). Hubungan Corporate Governance, Corporate Social Responsibilities and Corporate Financial Performance Dalam Satuan Continuum. Jurnal Akuntansi Dan Keuangan. 30-41. Mei. Vol (11) No.1.

Ningrum, R., Aditya, Fachrurrozie, Prabowo Y., Jayanto. 2013. Pengaruh Kinerja Keuangan, Kepemilikan Institusional Dan Ukuran Dewan Pengawas Syariah Terhadap Pengungkapan ISR. Accounting Analysis Journal.

Nurkhin, Ahmad. 2009. Corporate Governance Dan Profitabilitas: Pengaruhnya Terhadap Pengungkapan Tanggung Jawab Sosial Perusahaan. Tesis. Program Studi Magister Sains Akuntansi Universitas Diponegoro. 
Nuryaman. 2009. Pengaruh Konsentrasi Kepemilikan, Ukuran Perusahaan, Dan Mekanisme Corporate Governance Terhadap Pengungkapan Sukarela. Jurnal Akuntansi Dan Keuangan Indonesia. Volume (6). No. 1.

Othman, Rohana, A., Md Thani, dan E., K., Ghani. 2009. Determinant of Islamic Social Reporting Among Top Shariah-Approved Companies In Bursa Malaysia. Research Journal Of International Studies. October.

Peraturan Bank Indonesia Nomor 11/3/PBI/2009 Tentang Bank Umum Syariah.

Peraturan Otoritas Jasa Keuangan Nomor 29 Tahun 2016 Tentang Laporan Tahunan Emiten Atau Perusahaan Publik.

Peraturan Otoritas Jasa Keuangan Nomor 55 Tahun 2016 Tentang Penerapan Tata Kelola Bagi Bank Umum.

Priyatno, Duwi. 2014. SPSS 22 Pengelola Data Terpraktis. Yogyakarta. C.V Andi Offset.

Rahman, A., Abdul dan Abdullah A., Bukair. 2013. The Influence of the Shariah Supervision Board on Corporate Social Responsibility Disclosure by Islamic Banks of Gulf Co-Operation Council Countrie. Asian Journal of Business and Accounting 6 (2).

Rawi. 2008. Pengaruh Kepemilikan Manajemen, Institusi, Dan Leverage Terhadap Corporate Social Responsibility Pada Perusahaan Manufaktur Yang Listing Di Bursa Efek Indonesia. Tesis. Program Pascasarjana Universitas Diponegoro.

Ritha, Henny. 2016. Pengaruh Struktur Kepemilikan Dan Ukuran (Size) Perbankan Terhadap Kinerja Perbankan 2009-2014. Jurnal Ilmiah Ilmu Administrasi. September. Vol (VIII) No. 02.

Setiawan, Iwan, H., F., Asnawi, dan H., Sofyani. 2016. Apakah Ukuran, Profitabilitas, Dan Praktik Manajemen Laba Memengaruhi Tingkat Pelaksanaan Dan Pelaporan Islamic Social Reporting Pada Perbankan Syariah Di Indonesia?. Jurnal Dinamika Akuntansi Dan Bisnis (JDAB). 65-76. Vol (2)

Statistik Perbankan Syariah Desember 2008. Diakses Tanggal 2 Agustus 2017.

Statistik Perbankan Syariah Desember 2009. Diakses Tanggal 2 Agustus 2017.

Statistik Perbankan Syariah Desember 2010. Diakses Tanggal 2 Agustus 2017.

Statistik Perbankan Syariah Desember 2011. Diakses Tanggal 2 Agustus 2017.

Statistik Perbankan Syariah Desember 2012. Diakses Tanggal 2 Agustus 2017.

Statistik Perbankan Syariah Desember 2013. Diakses Tanggal 2 Agustus 2017.

Statistik Perbankan Syariah Desember 2014. Diakses Tanggal 2 Agustus 2017.

Statistik Perbankan Syariah Desember 2015. Diakses Tanggal 2 Agustus 2017.

Statistik Perbankan Syariah Desember 2016. Diakses Tanggal 2 Agustus 2017.

Sugiarto, Melanie. 2011. Pengaruh Struktur Kepemilikan Dan Kebijakan Dividen Terhadap Nilai Perusahaan Dengan Kebijakan Hutang Sebagai Intervening. Jurnal Akuntansi Kontemporer. Hal. 1-25. Januari. Vol (3) No. 1.

Sulistyawati, A., Ika, Rr., L., P., N., S., Surjanti dan D. Triyani. 2016. Pengungkapan Corporate Social Responsibility Pada Laporan Keuangan dan Determinasinya. Seminar Nasional IENACO.

Sulistyawati, A., Ika, dan Indah Yuliani. 2017. Pengungkapan Islamic Social Reporting Pada Indeks Saham Syariah Indonesia. Journal of Accounting \& Finance. Page 15-27. Vol (13) No. 2.

Surat Edaran Otoritas Jasa Keuangan Nomor 30 Tahun 2016 Tentang Bentuk Dan Isi Laporan Tahunan Emiten Atau Perusahaan Publik.

www.bankaceh.co.id

www.bankmuamalat.co.id

www.bankvictoriasyariah.co.id

www.bcasyariah.co.ic

www.bjbsyariah.co.id

www.bnisyariah.co.id

www.brisyariah.co.id

www.btpnsyariah.com

www.megasyariah.co.id

www.maybanksyariah.co.id

www.syariahbukopin.co.id

www.syariahmandiri.co.id 
Yuniarti, Eti. 2007. Analisis Pengungkapan Informasi Tanggung Jawab Sosial Pada Sektor Perbankan Di Indonesia. Tesis. Program Studi Magister Sains Akuntansi Universitas Diponegoro. 